\title{
KAJIAN ESTETIK DESAIN MATA UANG RUPIAH PADA MASA PEMERINTAHAN SOEKARNO PERIODE 1945-1949
}

\begin{abstract}
Afrizal *)
ABSTRACT

The foreign people's entry into Indonesia before Indonesian's Independence aimed to trade. They used transaction means they brought with them from their own countries. Such the means constituted gold and silver. When gold and silver were replaced with paper money by the incomers such as Dutch and Japanese as the means of transaction, such the type of paper money was also used as the legal means of payment in Indonesia. When Indonesians proclaimed their independence on August 17, 1945, such the form of transaction means was still used as the legal means of payment. The use of transaction means the incomers had brought as legal payment was considered as not suitable to the Indonesian personality; thus it should be replaced. For that reason, Indonesian government issued its own money form as the legal transaction means: Oeang Repoeblik Indonesia (ORI).

This study explored specifically the development of ORI design during Soekarno reign in 1945-1949 period. The main problem was explained using historical approach and fine art science such as esthetics and symbolism.

The result of research revealed that the development of ORI design was affected by several factors. The role of Indonesian government as the organizer of money circulation, the role of artists as ORI's designer who got full trust to select the picture theme to be applied to the money form, and Indonesian support to the publication of ORI who wanted to be independent from the colonial grip were internal factors supporting the development. The external factor was that the money used before Indonesian independence was not Indonesian official money.
\end{abstract}

Keywords: design development, rupiah currency, and esthetics.

\section{INTISARI}

Masuknya bangsa asing ke Indonesia sebelum bangsa Indonesia merdeka dengan tujuan berdagang mereka menggunakan alat transaksi yang dibawa dari negaranya masingmasing, alatransaksi itu berupa emas dan perak. Pada saat itu emas dan perak menjadi alatransaksi yang sah di Indonesia. Ketika uang emas dan perak diganti dengan uang kertas oleh bangsa pendatang seperti bangsa Belanda dan bangsa Jepang sebagai alatransaksi, jenis alatransaksi dengan bahan kertas tersebut juga diberlakukan sebagai pembayarang yang sah di 
Indonesia. Saat bangsa Indonesia memproklamasikan kemerdekaannya pada tanggal 17 Agustus 1945 bentuk alatransaksi itu masih digunakan sebagai alat pembayaran yang sah. Penggunaan bentuk alatransaksi yang dibawa oleh bangsa pendatang sebagai pembayaran yang sah setelah bangsa Indonesia merdeka, alatransasi itu dianggap tidak cocok dengan kepribadian bangsa Indonesia, dengan demikian jenis alatransaksi tersebut harus diganti. Oleh karena itu pemerintah Indonesia mengeluarkan bentuk uang sendiri sebagai alatransaksi yang sah yaitu: Oeang Repoeablik Indonesia (ORI).

Penelitian ini menggali secara khusus tentang perkembangan desain ORI pada masa pemerintahan Soekarno periode 1945-1949. Pokok permasalahan dipaparkan dengan pendekatan sejarah dan penggunaan ilmu seni rupa seperti: estetika dan simbolisme.

Hasil penelitian menggambarkan bahwa perkembangan desain ORI dipengaruhi beberapa hal. Peran pemerintahan Indonesia selaku pengatur peredaran uang, peran seniman sebagai desainer ORI yang mendapat kepercayaan penuh terhadap pemilihan tema gambar yang akan di aplikasikan kedalam bentuk uang, dan dukungan bangsa Indonesia terhadap terbitnya ORI yang ingin bebas dari cengkraman penjajah merupakan faktor internal yang mendukung perkembangan tersebut. Faktor eksternal adalah: uang yang digunakan sebelum bangsa Indonesia merdeka bukan uang resmi bangsa Indonesia.

Kata kunci: perkembangan desain, mata uang rupiah, dan estetika

\section{PENDAHULUAN}

Rupiah merupakan mata uang resmi Indonesia. Nama rupiah biasanya dikaitkan oleh banyak pihak sebagai pelafalan dari rupee, mata uang India, namun sebenarnya menurut Adi Pratomo, salah satu peneliti sejarah uang Indonesia, rupiah diambil dari kata rupee dalam bahasa Mongolia. Rupya sendiri berarti perak. Memang sama dengan arti rupee, namun rupiah sendiri merupakan pelafalan asli Indonesia karena adanya penambahan huruf ' $h$ ' di akhir kata rupia, sangat khas sebagai pelafalan orang-orang Jawa. Hal ini sedikit berbeda dengan banyak anggapan bahwa rupiah adalah salah satu unit turunan dari mata uang India. Rupee India sebenarnya juga dapat dikatakan sebagai turunan dari kata rupya itu sendiri, dengan begitu rupiah Indonesia memiliki tingkatan yang sama bukan sebagai unit turunan dari mata uang India tersebut. ${ }^{i}$

Yang dimaksud dengan mata uang adalah kesatuan-kesatuan logam atau kertas yang mempunyai bentuk dan tanda tertentu yang diberikan oleh atau atas nama pemerintah yang sah tanda-tanda itu berbentuk tulisan, gambar, dan dipingirnya terdapat garis-garis. ${ }^{\text {ii }}$

Ketika bangsa Indonesia memproklamasikan kemerdekaanya bangsa Indonesia saat itu perekonomiannya dalam keadaan tidak sehat, untuk melakukan perbaikan perekonomian pemerintah Republik Indonesia mencanangkan untuk membuat bentuk uang sendiri agar perkembangan perekonomian negara Republik Indonesia dapat diatur sendiri dan tidak ketergantungan dengan mata uang yang bukan uang resmi Republik Indonesia, 
bentuk uang tersebut dikenal dengan sebutan Oeang Repoeblik Indonesia (ORI). Oeang Repoeblik Indonesia (ORI) pada masa pasca kemerdekaan Republik Indonesia bentuk desain uang ini telah mengalami perkembangan cukup panjang. Eksistensi desain uang ORI ini telah mengantarkan bangsa Indonesia di kenal oleh dunia Internasional. Uang ORI ditetapkan sebagai awal terbentunknya uang rupiah Indonesia yang di resmikan pada tangga 29 Oktober 1946. Dalam penerbitan ORI pada masa pasca kemerdekaan Republik Indonesia, ORI terbagi dua jenis yaitu: ORI Jawa dan ORI Sumatera. Terbaginya penerbitan uang ORI pada masa pasca kemerdekaan Republik Indonesia hal ini dilakukan karena situasi keamanan dalam menyulai uang ORI kedaerah-daerah tersebut tidak aman. Oleh demikian daera-daerah terputus karena gangguan keamanan diperintahkan untuk membuat bentuk desain uang sendiri. Adanya perbedaan-perbedaan dalam bentuk desain uang ORI Jawa dan ORI Sumatera seperti: tema gambar, penanda tanganan, dan besar nilai nominal yang dicantumkan pada lembaran uang ORI. Hal tersebut tidak menyurutkan semangat dan kepercayaan bangsa Indonesia untuk mendukung serta menerimanya sebagai alatransaksi yang sah. ORI Jawa proses pembuatannya pada masa pasca kemerdekaan Republik Indonesia dilakukan dibeberapa daerah seperti: Surabaya, Malang, Jogyakarta, Solo dan saat itu di bawah "kejar-kejaran" dengan tentara Belanda yang hendak membatalkan terbentuknya ORI, dengan tujuan mengacaukan kestabilan keuangan nasional serta roda perekonomian bangsa Indonesia.

Bentuk uang ORI Jawa yang terbuat dari bahan dasar kertas, pada masa penerbitan tahun 1946-1948 mayoritas terdapat gambar Soekarno. Sedangkan yang diterbitan tahun 1949 atau dengan nama seri ORI baru, pada pecahan ini tidak terdapat potret para tokoh, maupun gambar flora dan fauna yang berbentuk realis, dan hanya terdapat bentuk ornamen organis dan garis-garis repetisi yang berilusi.

\section{Tinjauan Pustaka}

Ulasan tentang pemberlakuan ORI yang dirujuk dalam penelitian ini berasal dari buku Nichlany Soedardjo dan Perum Peruri, Banknotes and Coin from Indonesia, 1945-1990, 1991. Buku ini merangkan tentang pemberlakuan ORI yang disampaikan oleh Bung Hatta, selaku Wakil Presiden mengumumkan lewat corong RRI, sehari sebelum peredaran uang.

"Besok tanggal 30 Oktober 1946 adalah soeatoe hari jang mengandung sedjarah bagi tanah air kita. Rakjat kita menghadapi penghidoepan baru. Sejak moelai besok kita akan berbelanja dengan oeang kita sendiri, oeang jang dikeluarkan oleh Repoeblik kita sendiri. ${ }^{\text {"iii }}$

Ulasan tentang percetakan ORI yang dirujuk dalam penelitian ini berasal dari buku Y.B. Priyanahadi, Bersiaplah Sewaktu-waktu Dibutuhkan Perjalanan Karya Penerbit Percetakan Kanisuis 19222002, 2003. Buku ini menjelaskan tentang pemberian kepercayaan kepada percetakan Kanisius dalam mencetak 
beberapa pecahan uang kertas ORI yang di desain pada tanggal 17 Oktober 1945. Jurnal sejarah pemikiran, rekonstruksi, persepsi, Tilly " Collective Action" Revolusi , Kisah Tawanan Boven Digul, 2004 Tulisan ini menjelaskan ketika bangsa Indonesia memproklamasikan kemerdekaan, kondisi ekonomi yang diwarisi sangat buruk dengan angka inflasi yang relatif tinggi. Kondisi itu semakin meningkat setelah bangsa Indonesia memproklamasikan kemerdekaannya. Pada tulisan ini juga diterangkan rencana penerbitan ORI.

Pada 24 Oktober 1945 menteri keuangan A.A. Maramis menginstruksikan pada suatu tim dari serikat buruh percetakan G. Kolff \& CO Jakarta untuk melakukan peninjauan daerah guna menentukan tempat percetakan uang. Rencana penerbitan ORI semakin kuat terutama setelah mendapatkan daerah dari para buruh percetakan yang menguasai percetakan G. Kolff \& CO. Utusan buruh meminta agar pemerintah Republik Indonesia segera mengeluarkan uang sendiri. Setelah melakukan peninjauan ulang ternyata percetakan G. Kolff \& CO tidak cocok dan kurang layak dijadikan tempat percetakan, sehingga dilakukan peninjauan ulang sebagai alternatif di beberapa kota yaitu, Surabaya, Malang, Yogyakarta dan Solo.

Sejalan dengan upaya itu, Menteri Keuangan Mr. A. A Maramis membentuk panitia penyelengara pencetakan ORI, yang tertuang dalam surat keputusan No. 3/RD tanggal 7 November 1945. Panitia itu terdiri dari Ir. R. P. Soerachman sebagai pengawas, sedangkan panitia diketuai oleh T. R. B. Sabarudin ( Direktur Bank Rakyat
Indonesia ) dengan anggota H. A. Pandelaki ( Kementerian keuangan ), M. Tabrani ( Kementerian Penerangan ), S. Sugiono (Bank Rakyat Indonesia), E. Kusnadi (kas negara), R. Aboebakar Winangoen (Kementerian Keuangan), serta Oesman dan Agoes (keduanya mewakili Serikat Buruh Percetakan).Pembuatan desain dan bahan-bahan dasar berupa negatif kaca dilakukan oleh Percetakan Balai Pustaka, Jakarta dan Percetakan De Unie yang dikerjakan oleh Bujamin Surjohardjo. Di percetakan De Unie pulalah dibuat gambar Litografi.

Melihat keamanan di percetakan G.Kolff \& CO tidak aman, maka proses offset-nya untuk pertama kali dilakukan oleh percetakan RI salemba Jakarta, sebuah percetakan di bawah Kementerian Penerangan. Uang yang pertama dicetak adalah lembaran pecahan 100 rupiah. $^{\text {iv }}$

Tulisan Jai Singh Yadav, "Sejarah Mata Uang Indonesia", yang ditulis di harian KOMPAS, Jum'at 1 November 1991, menjelaskan periodisasi sejarah mata uang Indnonesia, secara garis besar dapat dibagi menjadi dua kurun waktu periode ke satu tahun 1945-1949, dan periode ke dua tahun 1950 hingga sekarang, serta menyampaikan peran Oeng Repoeblik Indonesia (ORI) terhadap perjuangan Bangsa Indonesia. ${ }^{v}$

Disebutkan bahwa ORI sangat berperan memperbesar eksistensi bangsa Indonesia ketika rakyat Indonesia menghadapi Belanda, dan juga berpengaruh terhadap makna dan tujuannya. Buku-buku yang terdapat dalam tinjauan pustaka ini dan buku-buku lain yang berkaitan dengan Oeang Repoeblik Indonesia belum sama sekali membahas 
tentang perkembangan desain Oeang Repoeblik Indonesia (ORI).

\section{Landasan teori}

Teori desain yang dikemukakan beberapa pendapat seperti: Victor Papanek, Walter Gropius, Archer, Harriet Goldstein and Vetta Goldstein. Teori ini menjadi landasan pokok dalam mengkaji perkembangan desain uang kertas Oeng Repoeblik Indonesia (ORI) yang di buat di pulau Jawa salah satu tempat pembuatan uang ORI yang ditetapkan oleh pemerintah Soekarno periode 1945-1959. Victor Papanek membagi enam unsur pokok yang harus diperhatikan dalam mendesain, yaitu sebagai berikut. (1) Method (metode), adalah interaksi antara alat, proses, dan bahan, (2) Use (kegunaan), adalah ketepatan bentuk yang ingin dicapai dengan penggunaan-nya, (3) Need (kebutuhan), adalah dalam membuat sebuah desain sangat pentingnya dalam memperhatikan kebutuhan-kebutuhan ekonomis, psikologis, spiritual, teknologis, dan inteletual, (4)Telesis, adalah penggunaan proses-proses di alam dan di masyarakat secara sadar dan bertujuan demi memperoleh sasaran tertentu. (5) Association, dalam pengertian association yang lebih menekankan kepada sebuah desain bahwa desain itu harus ada nilainilai seperti, keluwesan, formalitas, portabilitas, (6) Estetics atau keindahanvi. Dalam proses pembuatan desain uang kertas ORI belum ada sentralisasi pengawasan, sehingga prosesnya dipercayakan sepenuhnya pada seniman yang mendapat perintah oleh pemerintah, dan para seniman yang mendapat kepercayaan mendesain bebas mengekspresikan dirinya kedalan sebuah karya seni yang merupakan sebagai alat transaksi tersebut seperti yang diterangkan oleh Walter Gropius desain adalah suatu kereasi seniman untuk memenuhi kebutuhan tertentu dan cara tertentu pula. vii Pengertian desain sudah mengalami perkembangan dalam hal ini Archer menambahkan desain adalah salah satu bentuk kebutuhan badani dan rohani manusia yang dijabarkan melalui berbagai bidang pengalaman, keahlian, dan pengetahuannya yang mencerminkan perhatian pada apresiasi dan adaptasi terhadap sekelilingnya, terutama yang berhungan dengan bentuk, komposisi, arti, nilai, dan berbagai tujuan benda manusia. viii Harriet Goldstein and Vetta Goldstein membagi dua batasan desain, yaitu sebagai berikut. (1) keteraturan menunjuk kepada organisasi atau stuktur, (2) keindahan menunjuk pada karakter melalui interprestasi suatu gagasan. ${ }^{\text {ix }}$ Desain merupakan karya seni yang berkambang dari masa-kemasa yang memiliki konsep sesuai dengan kebutuhannya. Singkatnya waktu pemberlekuan Oeang Repoeblik Indonesia (ORI) pada masa pemerintahan Soekarno periode 1945-1959, Oeng Repoeblik Indonesia (ORI) telah banyak membatu kelangsungan negara Republik Indonesia dan bentuk-bentuk desain uangnyapun yang digunakan juga mengalami perkembangan. Analisis ini akan dipadukan dengan analisis fungsi seni yang berkaitan dengan perkembangan desain. Edmund Burke Feldman menegaskan bahwa dalam suatu pengkajian seni, gaya merupakan suatu konsep penting. Suatu hasil karya seni yang terdiri atas kreativitas penciptaan, seperti 
pertumbuhan, perkembangan, dan kualitas: serta gaya yang meliputi bentuk dan teknik yang ada di dalamnya dapat dilacak sesuai periodisasi sejarahnya. Setiap periode memiliki ciri khas sesuai dengan apa yang sedang terjadi dan berlaku pada saat itu. Pengkategorian seni pada umunya berdasarkan sifat dan kualitas, seperti bentuk dan unsur yang mengandung kesamaan tertentu dan sekaligus juga memperlihatkan sifat kualitas yang berbeda. ${ }^{x}$

Desain uang rupiah memiliki ciri-ciri dari kenegaraan bangsa Indonesia penuh dengan bentuk simbol analisis ini dipadukan dengan teori semiotik Udo Becker menjelaskan kata simbol berarti menggabungkan, mengumpulkan, menyatukan, dan mempertemukan. ${ }^{\text {xi }}$ Bentuk desain Oeang Repoeblik Indonesia (ORI) merupakan satu kesatuan bentuk yang menjadi simbol negara Republik Indonesia menyimpan banyak makna, maka penelitian ini menggunakan ilmu seni rupa seperti estetika dan simbolisme untuk mengungkapkan maknanya. Uang tidak hanya dipandang dari keindahan dan makna simbolnya saja. Agar uang dapat diterima oleh masyarakat maka analisis ini dipadukan dengan teori barang jika uang dianggap sebagai barang, maka uang itu tunduk pada hukum hukum nilai begitu juga barang - barang lainnya, tunduk pada hukum - hukum permintaan dan panawaran. Pada teori barang terdapat dua teori, yaitu : teori logam dan teori nominalisme. Teori logam, teori ini berlaku pada masa uang logan mulia uang yang terbuat dari emas atau perak. Setelah peralihan uang emas dan perak ke uang kertas, uang yang terbuat dari kertas pemberian nilai nominalnya hanya sembarangan tidak sama atau tidak sebanding dengan bahan dasar pembuatan uang, Davazanti menerangkan bahwa uang itu tidak mempunyai nilai intrinsik akan tetapi hanya mempunyai nilai yang diberikan. Jadi menurut teori nominalisme, uang itu bukan barang atau bukan benda melainkan sesuatu yang diberi fungsi tertantu, yaitu sebagai alat penengah dalam pertukaran. ${ }^{\text {xii }}$

\section{METODE}

1. Batas- batas objek dan subjek

Penelitian ini mengambil objek mata uang Oeang Repoeblik Indonesia (ORI) yang terbuat dari kertas pada masa pemerintah Soekarno periode 1945-1949 sebagai alat tukar yang sah. Perkembangan desain uang ini dipandang mampu menunjukkan karakter suatu kenegaraan yang mempunyai daya kekuasaan dalam mempersatukan bangsa Indonesia.

Adapun subjek kajian ini adalah faktorfaktor pendorong dan proses terjadinya perkembangan desain mata uang rupiah sebagai mata uang negara Indonesia yang merupakan alat pembayaran yang sah, sebagai atribut suatu negara dan juga salah satu pemersatu bangsa Indonesia.

2. Batas-batas Spasial dan Temporal

Batasan waktu yang ditentukan dalam kajian ini adalah dari tahun 19451949, semenjak ORI ditetapkan sebagai mata uang negara Indonesia, ORI sangat berperan dalam memperbesar eksistensi bangsa Indonesia ketika RI menghadapi bangsa Belanda, ketika itu ORI juga menjadi salah satu bedil bagi pertahanan 
$\mathrm{RI}$, serta mempertinggi wibawa pemerintah Republik Indonesia di mata dunia. ${ }^{\text {xiv }}$ JK Gailbrith menambahkan bahwa ORI merupakan instrument of revolusion, suatu alat revolusi dalam mempersatukan bangsa Indonesia ke dalam wilayah negara kesatuan Republik Indonesia. ${ }^{\mathrm{x}}$

Analisis yang dikembangkan.

Sebagai penelitian kulitatif, analisis kajian yang digunakan dengan rincian seperti : pertama, data yang berhasil dihimpun, baik data pustaka, visual, maupun lisan, dikelompokan dan diklasifikasikan sesuai dengan jenis, sifat, karakter data. Pengelompokan dan pengklasifikasian itu menyangkut pengaruh internal dan eksternal sebagai pendorong terjadinya perkembangan desain mata uang rupiah.

Kedua, hasil pengolahan data tekstual yang telah dikonfirmasikan dengan data visual, data lapangan, dan hasil wawancara dilanjutkan dengan pengujian dan interprestasi data dilandasi sifat kritis dan selektif. Dengan demikian data yang diperoleh layak diangkat sebagai fakta dalam pembahasan. Hasil pengolahan data ini akan manjadi bahan penjelas mengenai terjadinya proses perkembangan desain mata uang rupiah. Ketiga, analisis selanjutnya adalah memeriksa ada tidaknya perubahan fungsi dan tujuan pada desain uang rupiah. Keempat, merumuskan temuan mengenai proses terjadinya perkembagan desain mata uang rupiah.

\section{Isi dan Pembahasan}

Awal perang kemerdekaan RI, terdapat tiga mata uang yang beredar di Indonesia, sebagai alat tukar-menukar yang sah. Ketiga mata uang itu adalah mata uang Belanda (Hindia Belanda), uang kertas DE JAVASCHE BANK, dan uang kertas Jepang. Desain-desain mata uang tersebut mencerminkan dari ciri-ciri negara mereka masing-masing. Maka dari itu uang dapat dikatakan salah satu tanda dari suatu negara yang mencerminkan didalamnya terdapat suatu kekuasaan atau simbol dari suatu negara. ${ }^{\text {xvi }}$

Sejak terciptanya uang sebagai alat pembayaran yang sah dan pengukur satuan nilai, pada uang tersebut sudah terbentuk suatu simbol dari mana uang tersebut berasal. Simbol memegang peran penting dalam tingkah laku manusia. Tingkah laku manusia dalam berbagai hal tergantung dalam penggunaan simbol. Simbol adalah suatu yang maknanya diberikan oleh yang menggunakan simbol. Simbol dapat dibentuk benda-benda, warna, suara, atau gerak suatu benda. Simbol yang diberikan manusia penggunaannya berdasarkan pada aspek fisik atau ditentukan oleh unsur-unsur intristik di dalam bentuk fisiknya. Namun demikian, yang membedakan manusia dengan binatang adalah penggunaan simbol dalam tingkah lakunya. ${ }^{\text {xvii }}$

Crown

Zellerbach menambahkan uang dapat dijadikan sebagai simbol karena suatu abstraksi, yang disusun dari huruf-huruf perusahaan, dan suatu bentuk kegunaan perusahaan.

Selain menarik secara visual, juga berdaya guna: menggambarkan dinamisme dan juga gambaran kegunaan kertas tersebut. ${ }^{\text {xviii }}$

Awal kemerdekaan tahun 1945 pemerintah Indonesia melihat bangsa Indonesia masih dalam tidak menetu karena dikala itu bangsa Indonesai masih di 
pengaruhi oleh kaum penjajah. Sehingga bangsa Indonesia masih terpecah-pecah dan belum terbentuknya suatu negara dalam satu kesatuan negara Republik Indonesia. Seiring dengan kebutuhan dan tuntutan bangsa Indonesia sebagaimana keinginan sama dengan negara-negara lain, yang mempunyai hak dan serta mempunyai ciri-ciri negara sendiri. Begitu juga dengan alat yang digunakan sebagai pengadaan barang dan jasa yaitu, bentuk uang.

Maka dengan demikian pemerintah Indonesia mencanangkan membuat uang sendiri dengan nama Oeang Repoeblik Indonesia (ORI) $)^{\mathrm{xix}}$ agar kita tidak ketergantungan dengan mata uang asing serta menunjukan pada dunia bahwa bangsa Indonesia memiliki suatu negara yang berdaulat dan memiliki mata uang negara sendiri yaitu, Oeang Repoeblik Indonesia (ORI) sekarang lebih dikenal dengan Rupiah. Oleh karena itu pemerintah Indonesia memutuskan untuk mendesain uang sendiri yang mencerminkan bangsa dan negara Indonesia.

Pertama kali kita merdeka yang di pakai adalah uang kertas Jepang. Uang adalah salah satu yang mempunyai permasalah yang sangat komplek sehingga sulit untuk dirubah. Negara tidak gampang menarik uang dari peredarannya, jika kalau ditarik sistem perekonomian gagal. Sehingga uang Jepang tidak boleh diganti langsung karena rakyat masih memegang uang Jepang.

Bagitu juga pemasalahan yang dihadapi oleh Belanda, mereka mempunyai masalah dengan Australia sehingga uangnya belum bisa dikirim ke Indonesia.
Ketika Belanda kalah dengan Jepang pada tahun 1942, Indonesia masuk dalam jajahan Jepang. Selama Indonesia dikuasai oleh Jepang, Belanda sedang menyiapkan uang yang akan diberlakukan nantinya di Inadonesia. Yang mana uang itu bernama uang kertas NICA (Nederlands Indies Civil Administration). Sebelum Belanda datang ke Indonesia lagi, uang itu sudah siap dicetak dan dicetak pada tahun 1943 dipercetakan Amerika, yaitu: percetakan American Banknote Company.

Hal ini dilakukan oleh Belanda, karena negara Belanda masih diduduki Hitler. Oleh karena itu juga mereka tidak mencetak di Inggris, karena negara Inggris masih dalam keadaan perang. Belanda mencetak uang kertas NICA (Nederlands Indies Civil Administration) ini di Amerika, dan di letakkan pada bank-bank Australia. Waktu sekutu datang ke Indonesia, uang kertas NICA(Nederlands Indies Civil Administration) yang telah disiapkan tersebut tidak bisa masuk ke Indonesia. Terhalangnya pentribusian uang kertas NICA (Nederlands Indies Civil Administration) ke Indonesia disebabkan oleh sejumlah besar kapal-kapal Belanda yang membawa uang NICA (Nederlands Indies Civil Administration) dibaikot oleh Federasi Buruh Pelabuhan Australia yang mendukung pemogogkan para pelaut Indonesia . ${ }^{\mathrm{xx}}$

Sekutu mencetak uang kertas dengan tujuan untuk keperluan pembiayaan perang, dan uang itulah yang dibayarkan kepada tentara-tentaranya dalam memenuhi kebutuhannya pada masa perang kemerdekaan Indonesia. Pada 
hal uang kertas adalah surat tanda hutang. ${ }^{x x i}$

sebelum munculnya uang kertas, sistem uang adalah sistem emas dan perak. Di zaman dahulu uang adalah logam (emas dan perak), kita mempunyai emas dan perak sampai saat ini pun itu masih uang karena dapat dijual sewaktu waktu, tetapi jika kalau kita menggunakan uang kertas itu belum tentu dapat diterima jika di pergunakan diluar daerah penetapannya. Sedangkan uang emas atau perak, dapat diterima dimanapun kita berada.

Uang kertas bukan logam, harganyapun boleh di tulis sembarangan. Dan sistemnyapun juga tidak sama dengan uang logam, misalnya 1 golden sama dengan $1 \mathrm{gr}$, perak atau emas (tergantung ketetapan dari bahan yang digunakan), 2 golden sama dengan $2 \mathrm{gr}$, perak atau emas (tergantug ketetapan dari bahan yang digunakan), 2,5 golden sama denga 2,5 gr, perak atau emas (tergantung ketetapan dari bahan yang digunakan) tidak boleh lebih atau kurang, tidak bisa berubah-ubah, dan ukurannya pasti. Begitu juga dalam penerimaannya kita tidak merasa ragu ini uang dari siapa atau dari negara mana yang penting terbuat dari emas atau perak.

Uang logam adalah uang tunai, uang tunai ialah uang yang memiliki intrinsiknya sama dengan nilai nominalnya. Jadi, prinsip dari uang logam adalah intrinsik yang ada tertera di uang tersebut. xxii

Peristiwa ini terjadi pada masa

VOC (Vereenigde Oost-Indische Compagnie), menjelang bangkrut pada tanggal 27 Desember tahun 1782 untuk mengatasi krisis keuangan negara, maka VOC (Vereenigde Oost-Indische
Compagnie), mengeluarlah uang dalam bentuk surat kredit. Uang kertas pertama kali yang dikeluarkan oleh VOC (Vereenigde Oost-Indische Compagnie) yaitu berbentuk surat kredit dengan bunga $6 \%$. Uang kertas ini memiliki satu muka dengan teks Belanda, dan Arab Melayu, bentuk tulisan Arab bacaanya melayu. Di dalamnya juga menyatakan, surat ini diserahkan ke dia mereka akan membayar sekian, yang di maksud tetap tidak memegang kes tetapi di potong $6 \%$, dalam surat ini tidak dijelaskan hitunganya per tahun atau per bulan, tetapi ada juga yang menjelaskan $6 \%$ tanpa potongan.

Pembuatan bentuk uang kertas ini terdapat di beberapa daerah jalur perdagangan VOC (Vereenigde OostIndische Compagnie) seperti Batavia, Ambon, Banda, dan Ternate. Bentukbentuk lembaran uang kertas ini bukan uang yang dipegang oleh rakyat kecil tetapi ini adalah uang besar, uang antar Negara. Seperti gambar dibawah ini. ${ }^{\text {xiii }}$

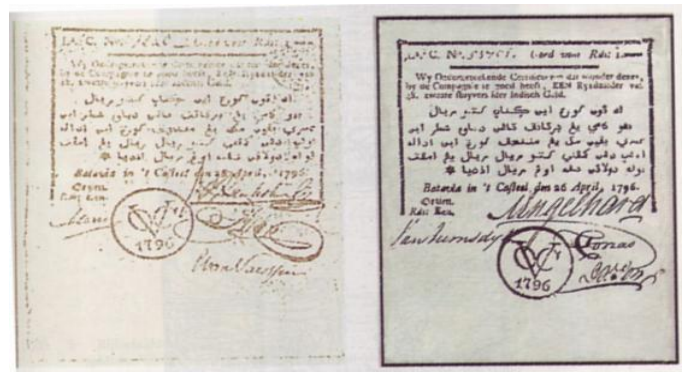

Gambar 1. Uang berbentuk surat kredit yang dibuat VOC (Vereenigde Oost-Indische Compagnie), Surat kredit dengan bunga $6 \%$ satu muka dengab teks Belanda dan Arab - Melayu dicetak di Batavia, 27 Desember 1782. (Sumber: Cataloque of Paper Money of The V.O.C.,Netherlands East Idies and Indonesia, from 1782 to 1981, 9., periksa katalog uang kertas Indonesia 1782-2010 Edisi ke 3, Jakarta, PT. Sugijaya Abadi Santosa, 2009, 24., Periksa 
Encylopedie van Nederlandsch-Inhie. G. Vissering: Munweezen, Hand Book, 1965, 7.)
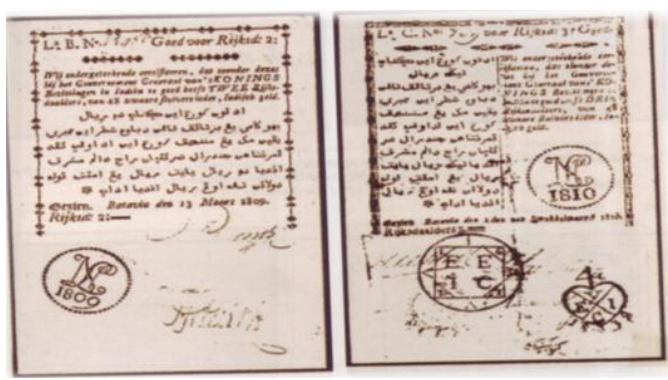

Gambar 2. Uang dalam bentuk surat kredit yang telah disepakati dari beberapa negara seperti dari VOC (Vereenigde Oost-Indische Compagnie) ke Belanda, dari Belanda ke Inggris. Surat kredit dua muka dengab teks Belanda dan Arab - Melayu cap LN 8109, memiliki 4 tanda tangan dan di belakang terdapat 2 cap merah. Uang ini dicetak di Batavia, 13 Maret 1807. (Sumber: Cataloque of Paper Money of The V.O.C.,Netherlands East Idies and Indonesia, from 1782 to 1981., periksa katalog uang kertas Indonesia 1782-2010 Edisi ke 3, Jakarta , PT. Sugijaya Abadi Santosa, 2009)

$$
\text { Sejak jatuhnya VOC }
$$

(Vereenigde Oost-Indische Compagnie) dalam sistem perdagangan dan dinyatakan bangkrut pada tahun 1799, semua harta dan kekuasaan diamabil alih oleh Belanda. Setelah mengambil alih kekuasaan yang dilakukan oleh Belanda terhadap VOC (Vereenigde Oost-Indische Compagnie), sistem kerajaan juga mengalami perubahan dari bentuk kerajaan menjadi Republik yaitu Republik Batavia. Sehingga mereka berdiri bukan atas nama Belanda tetapi Republik Batavia. Sedangkan sebagai Gubernur Jendralnya adalah H.W. Daendels pada tahun 1809.

Persoalan yang menyertai uang kertas negara adalah hutang negara. Hal itu dapat di amati pada uang kertas VOC (Vereenigde Oost-Indische Compagnie) yang dicetak di Batavia diterbitkan pada 27 Maret tahun 1807.
Pada uang tersebut menjelaskan, bahwa uang kertas itu surat tanda utang. Dan pada uang kertas itu terdapat beberapa pengakuan yang disahkan dalam bentuk cap, seperti pengakuan dari H.W. Daendels sebagai Gubernur Jendral yang baru di Hindia Belanda pada tahun 1809 yang menyatakan segala utang- piutang VOC (Vereenigde Oost-Indische Compagnie) ditanggung oleh Belanda, bentuk cap yang diterakan pada lembaran uang VOC (Vereenigde Oost-Indische Compagnie) tersebut dengan menggunakan inisial NL (Nederwig Napoleon). Begitu juga sebaliknya ketika Belanda kalah terhadap Inggris yang dipimpin oleh Raffles pada tanggal 4 Agustus 1811 ternyata Inggris juga mau menanggung hutang Belanda, dan Inggris juga membubuhkan bukti pengakuannya dengan inisial VEIC dan EEIC.

Setelah Belanda dan Sekutunya kembali menguasai Indonesia, mereka sudah mempersiapkan segala sesuatunya termasuk uang yang akan dipergunakan. Tetapi tidak semudah yang mereka bayangkan. Hal ini, disebabakan karena Sekutu hanya bisa menguasai sekitar pantai dan sedangkan bagian pedalaman di kuasai oleh Republik Batavia . Misalkan, Sekutu butuh beras atau bahan pokok lainnya jika kalau mereka menggunakan uang kertas NICA (Nederlands Indies Civil Administration) masyarakat tidak mau menerima, karena masyarakat menganggap uang kertas tersebut tidak banyak manfaatnya sebab jumlah uangnya terbatas. Banyaknya uang Jepang yang beredar dikalangan masyarakat dan penguasaan yang tidak menyeluruh oleh sekutu, sehingga mereka 
tidak bisa menggunakan uangnya dengan bebas maka untuk sementara waktu mereka menggunakan uang Jepang sebagai uang lintas batas. Dan terjadilah pemakain uang Jepang dalam transaksi antara penduduk dengan pemerintah Sekutu dan penduduk dengan Republik Batavia.

Pada tanggal 6 Maret 1946 sekutu mengumumkan pemberlakuan mata uang NICA (Nederlands Indies Civil Administration) di seluruh wilayah Indonesia atau yang telah diduduki oleh pasukan AFNEI (Allied Forces Netherlands East Indies) di bawah komando Letjen Sir Montagu Stopford. ${ }^{x \times i v}$

Kebijakan ini diprotes keras oleh pemerintah $\mathrm{RI}$, karena melanggar persetujuan bahwa masing-masing pihak tidak boleh mengeluarkan mata uang baru selama belum adanya penyelesaian politik. Seperti yang disampaikan oleh Perdana Mentri RI Sutan Sjahrir menjelaskan, makloemat presiden RI No.1/10 tanggal 3 Oktober 1945 menyatakan berlakunya uang penduduk Jepang dan uang Hindia Belanda sebelum perang sebagai tanda pembayaran yang sah di wilayah $\mathrm{RI},{ }^{\mathrm{x} v}$ namun protes keras ini diabaikan oleh AFNEI (Allied Forces Netherlands East Indies).

Mata uang NICA digunakan AFNEI

(Allied Forces Netherlands East Indies) untuk membiayai operasi-operasi militernya di Indonesia dan sekaligus mengacaukan perekonomian nasional, sehingga muncul krisis kepercayaan rakyat terhadap kemampuan pemerintah RI dalam mengatasi persoalan ekonomi nasional. Karena protesnya tidak ditanggapi, maka pemerintah RI mengeluarkan kebijakan yang melarang seluruh rakyat Indonesia menggunakan mata uang NICA(Nederlands Indies Civil Administration) sebagai alat tukar. Langkah ini sangat penting karena mata uang NICA(Nederlands Indies Civil Administration) berada di luar kendali pemerintah RI, sehingga menyulitkan perbaikan ekonomi nasional.

Oleh karena AFNEI (Allied Forces Netherlands East Indies) tidak mencabut pemberlakuan mata uang NICA, maka pada tanggal 26 Oktober 1946 pemerintah $\mathrm{RI}$ segera memberlakukan uang ORI (Oeang Republik Indonesia) sebagai alat tukar yang sah di seluruh wilayah RI. Sejak saat itu mata uang Jepang, mata uang Hindia Belanda dan mata uang De Javasche Bank dinyatakan tidak berlaku lagi.

Pernyataan itu ditegaskan dalam U.U.No.Ss/1/35, menetapkan bahwa ORI mulai berlaku sebagai alat pembayaran yang sah pada tanggal 29 Oktober 1946, malam pukul 12 , sedangkan pada saat itu juga uang yang berlaku sebelumnya (uang Jepang dan Hindia Belanda) tidak belaku lagi di Jawa dan Madura. ${ }^{\text {xvi }}$ Dengan demikian hanya ada dua mata uang yang berlaku yaitu uang kertas ORI (Oeang Repoeblik Indonesia) dan uang kertas NICA(Nederlands Indies Civil Administration). Masing-masing mata uang hanya diakui oleh yang mengeluarkannya. Jadi ORI hanya diakui oleh pemerintah RI dan mata uang NICA(Nederlands Indies Civil Administration) hanya diakui oleh AFNEI (Allied Forces Netherlands East Indies).

Pada masa revolusi kemerdekaan Republik Indonesia pada tanggal 17 Agustus 1945 negara Indonesia selalu 
mendapat tekanan oleh penjajah yang ingin menguasai kembali Negara Republik Indonesia.

Sehingga dengan berbagai macam cara mereka lakukan untuk menghancurkannya seperti, bagaimana merusak kepercayaan penduduk terhadap kemampuan pemerintah RI dan bagaimana mengacaukan perekonomian nasional, langkah-langkah itu dilakukannya dengan cara pemaksaan pemberlakuan uang NICA (Nederlands Indies Civil Administration), maka munculah krisis kepercayaan rakyat terhadap kemampuan pemerintah RI dalam mengatasi persoalan ekonomi nasional.

Untuk

mengembalikan kepercayaan rakyat kepada pemerintah RI, maka pemerintah dengan segera mengambil sikap agar semua dapat dipulihkan, untuk itu pemerintah Indonesia mencetak uang kertas yang lebih kenal dengan ORI (Oeang Repoeblik Indonesia)

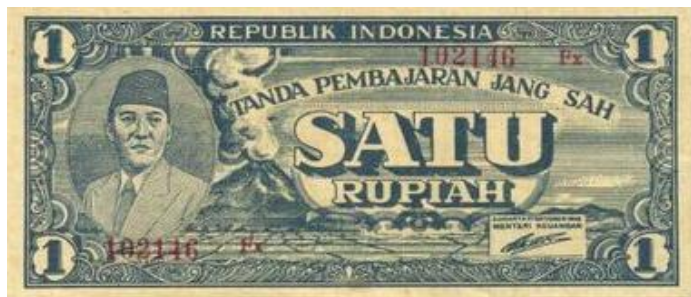

Gambar 4. Uang ORI pecahan Satu Rupiah (Sumber :Katalog uang kertas Indonesia 1782-2010 Edisi ke 3, Jakarta, PT. Sugijaya Abadi Santosa, 2009)

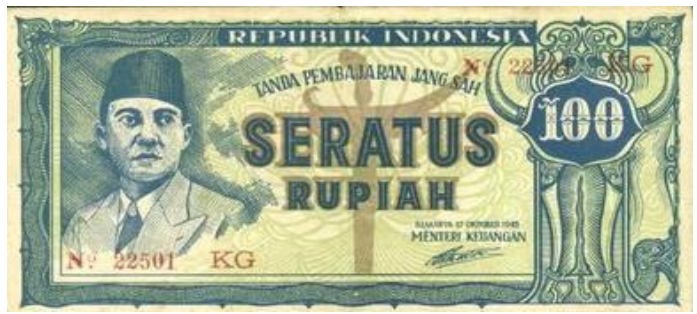

Gamabar 5. Uang ORI pecahan Seratus Rupiah (Sumber :Katalog uang kertas Indonesia 1782-2010 Edisi ke 3, Jakarta, PT. Sugijaya Abadi Santosa, 2009)
Dalam mendesain uang kertas ORI (Oeang Repoeblik Indonesia) pada masa repolusi kemerdekaan penuh dengan berbagai tekanan, seperti tekanan politik, ekonomi, dan budaya. Hal ini dapat dilihat sebagai contoh pada uang kertas dengan pecahan 1 rupiah dan 100 rupiah. Dampak tekanan itu tidak hanya berlaku untuk bangsa penjajah, tetapi antara pimpinan RI dengan penduduknya sendiri juga terjadi. Jika kalu melihat proses pembuatan desain ORI (Oeang Repoeblik Indonesia), desain itu sangat begitu jelas adanya suatu pemaksaan atas kehendak dari pencetus ide.

Penggagas pembuatan uang kertas ORI (Oeang Repoeblik Indonesia) adalah Soekarno pada tanggal 17 Oktober 1945. Pada masa revolusi kemerdekaan RI dengan keadaan yang tidak aman, tetapi bangsa Indonesia harus mengambil sikap dan tindakan cepat untuk keluar dari kekrisisan kepercayaan rakyat serta memperbaiki sistem ekonomi nasional. Sehingga mendesain uang kertas ORI (Oeang Repoeblik Indonesia) tidak ada sistem pegkonsultasian, untuk menentukan bahwa desain tersebut layak diterbitkan apa tidak.

Dalam situasi yang tidak memungkinkan maka dalam mendesain ORI (Oeang Repoeblik Indonesia) yang pertama merupakan ide dari Soekarno dan pada proses mendesainpun mendapat pengawasan penuh darinya. Hal ini juga di jelaskan oleh pelukis ORI (Oeang Repoeblik Indonesia) pertama Soerono bahwa dalam penugasan dirinya tidak adanya suatu pemberitahuan kepada yang bersangkutan, yang ada hanya anda diutus oleh Djaruman atas perintah Bung Karno. Begitu juga 
dalam proses mendesain tidak adanya suatu tawar menawar antara pelukis dengan pemberi pekerjaan.

Dalam pemilihan gambar, contoh gambar sudah disiapakan oleh penggagas, seperti foto penggagas sendiri yaitu Soekarno. Waktu proses mendesain, Soekarno selalu mengomentari hasil dari lukisannya dan menolak beberapa kali contoh hasil lukisan potretnya dan sering dia mengatakan kurang gantenglah atau kegantenganlah dan masih banyak lagi. Dengan banyaknya komentar yang dilontarkan akhirnya desain uang tersebut dapat terselesaikan dalam tiga bulan. Soerono menambahkan bahwa aseli dari desain uang ORI (Oeang Repoeblik Indonesia) tersebut $50 \times 100 \mathrm{~cm}$. ${ }^{\text {xvii }} \mathrm{Di}$ sebabkan dengan keterbatasan alat untuk membuat sebuah desain agar desain tetap kelihatan maksimal, untuk itu dilakukan pemotretan. Hal ini dilakukan beberapa kali sampai mencapai ukuran normal. Selain demikian juga untuk mendapatkan hasil yang maksimal.

Melihat dari bentuk desain ORI (Oeang Repoeblik Indonesia) pertama, desain-desain tersebut tidak lepas dari pengaruh desain uang Bangsa pendatang seperti bentuk desain uang kertas Hindia Belanda, desain uang kertas Jepang, dan desain uang kertas NICA(Nederlands Indies Civil Administration) atau desain uang kertas DE JAVASCHE BANK. Ini dapat dilihat pada cara penganbilan obyek dan pengaturan komposisi gambar.

Mengacu pada gambar uang kertas pecahan 100 rupiah, pada desain tersebut benar-benar mencerminkan kepribadian Soekarno.
Melihat dari latarbelakang keyakinan Soekarno. Soekarno adalah merupakan salah seorang yang kuat memahami kekuatan benda-benda pusaka seperti keris. Karena keris pada zaman dahulu dipercayai bagi yang mempercayai mempunyai bagian-bagian yang dapat menanggulangi sesuai pada bagiannya. Bagian-bagian itu diantaranya adalah contoh dengan keris sesorang bertambah berani, dengan keris dapat mendatangkan rezeki, dengan keris dapat memberikan ketentraman, dengan keris dapat meningkatakan pangkat yang tinggi, dengan keris dapat dijauhi oleh pencuri dan dengan keris dapat menigkatkan kemakmuran, dan masih banyak yang dapat dilakukan dengan keris.

Sedangkan gambar kepala Banteng yang dipilih bagian dalam mendesain ORI (Oeang Repoeblik Indonesia), karena Banteng melambangkan suatu keperkasaan. Banteng merupakan binatang yang tidak pernah ragu dalam menghadapi musuh walaupun yang dihadapi sekalipun memiliki taring dan berkuku yang tajam. Hal ini juga tedapat pada lukisan Raden Saleh yang berjudul antara hidup dan mati.

Desain ORI (Oeang Repoeblik Indonesia) yang memilki pecahan 100 rupiah ini adalah merupakan salah satu bentuk gambaran bangsa Indonesia dalam mempertahan kemerdekaan di kala itu. Walaupun tidak ada mengadakan pengoreksian desain dengan aturan pendesainan, tetapi dikala itu desaindesain ORI (Oeang Repoeblik Indonesia) yang diciptakan tidak sembarang orang, dalam arti bukan orang-orang yang tidak tahu seni. Melainkan orang-orang yang cinta dengan karya seni seperti Soekarno. 
Soekarno adalah salah satu kolektor seni dikala itu sehingga mereka berani menyampaikan idenya karena mereka tahu persis mana yang pantas dan yang tidak. Sehingga hasil desainnya tidak diragukan dari kepantasannya.

Untuk mengetahui perkembangan dari desain ORI, desain ORI pada zaman pasca kemerdekaan RI perkembangannya di pengaruhi beberapa faktor yaitu: faktor internal dan eksternal. Faktor internal yaitu: 1) peran pemerintah Indonesia selaku pengatur keuangan negara., 2) Desain ORI lebih banyak dibuat atas imajinasi seniman sebagai desainernya. Seperti apa yang diterangkan oleh Soerawi Dibjo Pramodjo salah seorang desainer ORI yang berkesempatan mendesain ORI pecahan dua puluh lima rupiah, mengatakan untuk menggambar uang cuma memerlukan waktu lima hari, karena desainnya masih sederhana cuma gambar banteng dan tulisan alat pembayaran yang sah. Dan selama mendesain uang semua gagasan gambar berasal dari pendesainnya

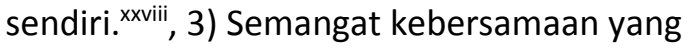
ingin bebas dari cengkraman penjajah dalam memberikan dukungan kepada ORI(Oeang Repoeblik Indonesia). Bentuk dukungan dan kegembiraan itu ditunjukan oleh masyarakat kepada Republik Indonesia dengan berbagai macam cara seperti, pemberian uang satu rupiah oleh pemerintah kepada setiap penduduk dilakukan dengan upacara yang khidmat, dan uang-uang itu diberikan dalam bungkusan merah putih, sedangkan ditempat-tempat yang lain pemberiannya disertai dengan selamatan dan berdo'a bersama. ${ }^{\text {xxix }}$ Faktor eksternal yaitu: bentuk uang yang digunakan sebagai alatransaksi sebelum ORI diberlakukan seperti: uang kertas Belanda dan uang kertas Jepang dianggapa tidak cocok dengan kepribadian bangsa Indonesia. Maka jenis uang ini harus diganti.

\section{Kesimpulan}

Uang adalah berfungsi sebagai alat tukar atau medium of exchange yang dapat mempermudah pertukaran. Selain itu, uang juga berfungsi sebagai alat penyimpan nilai (valuta) karena dapat digunakan untuk mengalihkan daya beli dari masa sekarang ke masa mendatang. Ketika seorang penjual saat ini menerima sejumlah uang sebagai pembayaran atas barang dan jasa yang dijualnya, maka ia dapat menyimpan uang tersebut untuk digunakan membeli barang dan jasa di masa mendatang.

Mengacu pada fungsi uang, uang tidak hanya berfunsi sebagai alat pembayaran yang sah. Tetapi jauh lebih besar dari fungsi nominalnya, yaitu walau hanya sebuah gambar tetapi gambar itu dapat menjadi unjung tombak dari bentuk kekuasaan pada suatu negara yang berdaulat. Oleh karena itu pentingnya sebuah desain dalam menciptakan uang, yang dapat mencerminkan suatu negara yang berdaulat. Desain-desain uang kertas dari dahulu hingga sekarang selalu mengalami perkembangan begitu juga dengan desain ORI. Sejak pertama kali desain ORI dibuat desain ini sudah memiliki kelayakan untuk dieterbitkan karena desainnya sudah memiliki keharmonisan. Artinya sudah memenuhi persyaratan. Walaupun hasil cetakannya belum begitu bagus dibandingkan dengan cetakan uang asing. 
Terdapatnya desain ORI yang kurang layak untuk terbit tetapi diterbitkan, Itu bukan dari ketidak mampuan RI untuk membuat desain uang. Hal ini terjadi karena tidak ada suatu kebebasan dalam mendesain uang. Waktu RI membuat uang, prosesnya dilakukan dengan sembunyi-sembunyi sebab kalau kedapatan oleh musuh, sipembuat desain keselamatannya bisa terancam.

\section{DAFTAR PUSTAKA}

al-Dimasyqi, Ja'far bin Ali. 1977. al- Isyarat ila Mahasin al-Tijarah, Tahqiq, alBasyari al-Syorbaji. Alexandria: alGhad.

AP, Suryadi. Pelukis Uang ORI Pertama Soerono, Harian Sinar Harapan, 26 Oktober 1985.

Becker, Udo. 1992. The Continuum Encyclopedia of Symbols. New York.

Cataloque of Paper Money of The V.O.C.,Netherlands East Idies and Indonesia, from 1782 to 1981.

Darmawan, Indra.1992. Uang dan Perbankkan. Jakarta: Rineka Cipta .

Dimyati, Edy. 2010. Panduang Sang Petualang 47 Museum Jakarta. Jakarta: PT.Gramedia Pustaka Utama.

Duncan, Hugh Dalziel. 1962. The Establishment of Money as Symbol of Comunity Life Money as a Form of Transcenden. terjemah Alfian, Sosiologi Uang. Yogayakarta: Pustaka Pelajar.
Feldman, Edmund Burke. 1967. Art As Image and Idea Englewood Cliffs. New Jersey: Prentice-Hall, Inc.

Becker, Udo. 1992. The Continuum Encyclopedia of Symbols. New York.

Goldstein, Harriet. and Vetta Goldstein. 1960. Art in Everyday Live New York: The Macmillan Compony, Fourth Edtion.

Hasan, Ahmad. 2005. Mata Uang Islam, Telaah Komprehensif Sistem Keuangan Isalam. Jakarta: PT. Raja Grafindo Persada.

Sumanang dan Rasjid, S.M. Bung Hatta: mengabdi pada tjita-tjita perdjoangan bangsa. Jakarta: Panitia Peringatan Ulang Tahun Bung Hatta, 1972.

H. Maslow, Abraraham.1970. Motivation and personality, Hand Book New York, Harper \& Row.

Haryono, Timbul. 2008. Seni Pertunjukan dan Seni Rupa, Dalam Perspektif Ekreologi Seni. Surakarta: ISI PresSolo.

Haryono,Timbul. 2001. Logam dan Peradapan Manusia. Yogyakarta: Philosophy Press

Handjaja, Madsuri. 2009. "65 Tahun Indonesia Merdeka",Katalog Uang Kertas Indonesia 1782-2010, edisi ke-3. Jakarta: Buana Printing. 
Jurnal sejarah pemikiran, rekonstruksi, persepsi, Tilly "Collective Action" Revolusi, Kisah Tawanan Boven Digul .2004. Yayasan Masyarakat Sejarah Indonesia: Obor Indonesia.

Lokwood, Rupert. 1983. Armada Hitam, Angkatan Laut Australia Mendaratkan Rupiah. Jakarta: Gunung agung .

Montagu. 1984. Sejarah Nasional Indonesia, edisi ke-4. Jakarta: Rinika Cipta. jilid 6.

Osborne, Harnold. 1972. Aesthetics. London and Prescot: Oxford University Press.

Priyanahadi, Y.B. 2003. Bersiaplah Sewaktu-waktu Dibutuhkan Perjalanan Karya Penerbit Percetakan Kanisius 1922-2002, 2003. Jogjakarta: Kanisius.

Papanek, Victor. 1973. Design For The Real World: Human Ecology and Social Change, Bantam Books, Toronto,New York, London.

"Riwajat Pedjoengan Oeang Repoeblik", Tempo, 30 Maret 1985.

Rosidi, Ajip. 1986. Biografi Sjafruddin Prawiranegara, Lebih Takut Kepada Allah SWT. Jakarta: Inti Idayu Press

Santosa, Sugijaya Abadi. 2009. Katalog Uang Kertas Indonesia 1782-2010 Edisi ke 3. Jakarta : PT. Sugijaya Abadi Santosa.
Sachri, Agus. 2005. Budaya Rupa, Desain, Arsitektur, Seni Rupa dan Kriya. Jakarta: Erlangga.

Sachari, Agus. 2000. Sejarah dan Perkembangan Desain dan Dunia Kesenirupaan di Indonesia. Bandung: ITB

Soubari, Muhamad. "Antara" di kutip oleh harian Belanda "Nieuwagier" tanggal 1 November 1947.

Soedardjo, Nichlany. 1991. Banknotes and Coin from Indonesia, 1945-1990. Jakarta: Yayasan Serangan Umum 1 Maret 1949 dan Perum Peruri.

Weatherford, Jack. 2005. Sejarah Uang (The History of Money) terjemah, Noor Cholis. Yogyakarta: Bentang Pustaka.

Yadav, Jai Singh. "Sejarah Mata uang Indonesia", harian KOMPAS, Jum'at 1 November 1991.

Zellerbach,Crown. dalam Arthur Asa Berger, Signs in Contemporary Cultur, An Introdution to Semiotics, terjamah Marianto, M. Dwi. dan Sunarto. 2005. Tanda-tanda Dalam Kebudayaan Kontemporer. Yogyakarta: Tiara Wacana Yogyakarta.

\section{Sumber Pendukung}

1. Adi Pratomo Peneliti dan Kolektor Uang Kuno

2. Hamid Ponco Wibowo, peneliti eksekutif di Biro Kebijakan. Pengedaran Uang, 
Direktorat Pengedaran Uang Bank Indonesia.

3. Agus Santoso Kepala Museum Uang Bank Indonesia Jakarta.

i Wawancara dengan Adi Pratomo 28 September 2010, di kediamannya Jl. Raya Darmo Permai Selatan no.71, Surabaya., dan baca Timbul Haryono, Seni Pertunjukan dan Seni Rupa, Dalam Perspektif Ekreologi Seni (Surakarta: ISI PresSolo,2008), 71.

ii Indra Darmawan, Uang dan Perbankkan

(Jakarta: Rineka Cipta 1992), 26.

iiiPeriksa Nichlany Soedardjo, Banknotes and Coin from Indonesia, 1945-1990, (Jakarta: Yayasan Serangan Umum 1 Maret 1949 dan Perum Peruri,1991), 5.

ivJurnal sejarah pemikiran, rekonstruksi, persepsi, Tilly "Collective Action" Revolusi, Kisah Tawanan Boven Digul, (Jakarta: Yayasan Masyarakat Sejarah Indonesia, 2004), 50-52.

vai Singh Yadav, Sejarah Mata uang Indonesia, yang ditulis di harian KOMPAS, Jum'at 1 November 1991.

viperiksa Victor Papanek, Design for the Real World: Human Ecology and Social Change, Bantam Books, Toronto, New York, London, 1973, 139-142.

viiAgus Sachri, Budaya Rupa, (Desain, Arsitektur, Seni Rupa dan Kriya ) (Jakarta: Erlangga, 2005), 5.

viiiAgus Sachari, Sejarah dan

Perkembangan Desain dan Dunia Kesenirupaan di Indonesia (Bandung: ITB, 2000), 14.

ixHarriet Goldstein and Vetta Goldstein, Art in Everyday Live New York: The Macmillan Compony, Fourth Edtion, 1960, 3-4.

xperiksa Edmund Burke Feldman, Art As Image and Idea (Englewood Cliffs,New Jersey: Prentice-Hall, Inc., 1967), 8.

xiUdo Becker, The Continuum Encyclopedia of Symbols, New York, 1992, 5.

xiiDavazanti, dalam Indra Darmawan, Uang dan Perbankkan (Jakarta: Rineka Cipta, 1992), 40.

xiiiperiksa Bung Hatta, 70 Tahun, Bung Hatta mengabdi Pada Tjita-tjita Perjoang Bangsa, 1972, baca dalam Jurnal sejarah pemikiran, rekonstruksi, persepsi, Tilly "Collective Action" Revolusi, Kisah Tawanan Boven Digul (Jakarta: Yayasan Masyarakat Sejarah Indonesia, Obor Indonesia, 2004), 45. dan periksa juga Ajip Rosidi, Biografi Sjafruddin Prawiranegara, Lebih Takut Kepada Allah SW, ( Jakarta: Inti Idayu Press 1986), 56.

xiv Bung Hatta, 70 Tahun, 1972, 25.

xv Jai Singh Yadav, 1991, 1. xvi Jack Weatherford, Sejarah Uang (The History of Money) terjemah, Noor Cholis, (Yogyakarta: Bentang Pustaka, 2005), 4.

xvii Leslie A. White, The sciene of Culture:A Study of Man and Civilization ( New York: Grove Press, Inc., 1949) dalam Timbul Haryono, Logam dan Peradapan Manusia (Yogyakarta: Philosophy Press, 2001), 21.

xviiiCrown Zellerbach, dalam Arthur Asa Berger, Signs in Contemporary Cultur, An Introdution to Semiotics, terjamah M. Dwi Marianto dan Sunarto, Tanda-tanda Dalam Kebudayaan Kontemporer (Yogyakarta: Tiara Wacana Yogya, 2005), 116

xix Jurnal sejarah pemikiran, rekonstruksi, persepsi, Tilly "Collective Action" Revolusi, Kisah Tawanan Boven Digul (Yayasan Masyarakat Sejarah Indonesia: Obor Indonesia, 2004), 44.

xx Montagu, Sejarah Nasional Indonesia, edisi ke-4 (Jakarta: Rinika Cipta, 1984) jilid 6. Dan baca Rupert Lokwood, Armada Hitam, Angkatan Laut Australia Mendaratkan Rupiah, (Jakarta: Gunung Agung , 1983), bab 11.

xxi Madsuri Handjaja dan kawan-kawan, "65 Tahun Indonesia Merdeka", Katalog Uang Kertas Indonesia 1782-2010, edisi ke-3 (Jakarta: Buana Printing, 2009), 1.

xxii Ja'far bin Ali al-Dimasyqi, al- Isyarat ila Mahasin al-Tijarah, Tahqiq, al-Basyari al-Syorbaji (Alexandria: al-Ghad,1977), 22-23. baca dalam Ahmad Hasan Mata Uang Islam, Telaah Komprehensif Sistem Keuangan Isalam (Jakarta: PT. Raja Grafindo Persada,2005),71.

xxiii Madsuri Handjaja dan kawan-kawan ,2009,1-11.

xxiv Nichlany Soedardjo, Banknotes and Coin From Indonesia, 1945-1990, (Jakarta: Yayasan Serangan Umum 1 Maret 1949 dan Perum Peruri,1991), 5.

xxv Nichlany Soedardjo, 1991, 8.

xxvi Nichlany Soedardjo, 1991, 12.

xxvii Suryadi AP, "Pelukis Uang ORI Pertama Soerono", Harian Sinar Harapan", 26 Oktober 1985. xxviii" Riwajat Perjoengan Oeang Repoeblik", Tempo, 30 Maret 1985., periksa Ajip Rosidi, Biografi Sjafruddin Prawiranegara, Lebih Takut Kepada Allah SWT, ( Jakarta: Inti Idayu Press 1986), 57.

xxix Muhamad Soubari, "Antara" di kutip oleh harian Belanda "Nieuwagier" tanggal 1 November 1947. 
166 ] CORAK Jurnal Seni Kriya Vol. 2 No.2, Nopember-April 2014 